\title{
Monitoring of the Hydrological Balance in the Area of the Kiskunság National Park Directorate
}

\author{
Bence BOLLA ${ }^{\mathrm{a}, \mathrm{b}}$ - Tamás Márton NÉMETH ${ }^{\mathrm{c}}$ \\ ${ }^{a}$ Department of Forestry, Kiskunság National Park Directorate, Kecskemét, Hungary \\ ${ }^{\mathrm{b}}$ Institute of Geomatics and Civil Engineering, University of Sopron, Sopron, Hungary \\ ${ }^{c}$ Government Office of Bács-Kiskun County, Labour Office of Kecskemét, Kecskemét, Hungary
}

\begin{abstract}
The aim of this paper is to show how hydrological measurements made in forests and grasslands can contribute to the conservation treatment of ecologically significant habitats. The study was carried out in three different forest stands and their surrounding grasslands in the area of the Kiskunság National Park Directorate between 2012 and 2015. Different methods were applied during the research of the water balance. The average values of canopy interception were $23 \%$ in the Scots pine stand and $19.2 \%$ in the grey poplar stand. Rainfall quantity, intensity, and dispersion as well as tree structure and health greatly influenced interception. The transpiration values were 205 $\mathrm{mm}$ in the coniferous stand, $405 \mathrm{~mm}$ in the deciduous stand, and $370 \mathrm{~mm}$ in the black locust stand. The water balance of the habitats show that the water uptake is much lower in the grasslands than it is in the surrounding forest stands.
\end{abstract}

precipitation / soil moisture / interception / water balance / forest stands

Kivonat - Hidrológiai vizsgálatok a Kiskunsági Nemzeti Park Igazgatóság területén. Jelen vizsgálat a különböző erdőállományokban és gyepterületeken végzett hidrológiai mérések alapján egészíti ki, támasztja alá az egyes ökológiai szempontból jelentős élőhelyek szakszerü természetvédelmi kezelését. A vizsgálatok a Kiskunsági Nemzeti Park Igazgatóság működési területén elhelyezkedő három erdőrészletben és közvetlen közelükben lévő gyepterületen folytak 2012-2015 között. Munkánk során különféle módszereket alkalmaztunk az élőhelyek vízháztartásának vizsgálatához. A koronaintercepció átlagos értéke az erdei fenyves állományban $23 \%$, ezzel szemben a szürke nyáras állományban 19,2\% volt. Az intercepció mértékét döntően befolyásolta a leérkező csapadék mennyisége, intenzitása, eloszlás és a faállomány szerkezeti jellemzői és egészségi állapota. A transpiráció értéke a tülevelü állományban $205 \mathrm{~mm}$, a nyáras faállományban $405 \mathrm{~mm}$ és az akácos állományban $370 \mathrm{~mm}$ volt. Az élőhelyek vízháztartásának vizsgálata során megállapítottuk, hogy a vizsgált tisztások vízfogyasztása jóval alacsonyabb, mint a mellette elhelyezkedő erdőállományoké.

csapadék / talajnedvesség / intercepció / vízháztartás / erdőállományok

\footnotetext{
* Corresponding author: tomanemeth@gmail.com; H-4400 NYÍREGYHÁZA, Westsik Vilmos u. 23/A, Hungary
} 


\section{INTRODUCTION}

Due to the implementation of several programmes, such as the Afforestation Program of the Great Hungarian Plain, the Poplar Program, and the Pine Program, forest extension has increased almost threefold in Hungary since 1920. Recovering the loss of forest area proved a challenge for foresters. Nonetheless, their committed professionalism combined with the above mentioned afforestation programmes has made the region between the Danube and the Tisza rivers the most afforested part of the Great Plain. Mainly alien species (Pinus sylvestris, Pinus nigra, Robinia pseudoacacia) were planted here in order to improve the sand in the region. Environmental organizations have criticized these afforested plantations in the Danube-Tisza sand ridge area whereas governmental conservation management groups have more varied perspectives about these plantations as several National Park Directorates manage forest stands in the area.

Groundwater levels have decreased significantly in the region between the Danube and the Tisza since the 1970s, and the tendency can be seen even today (Pálfai 1993, 2010). Many researchers have tackled this important issue and have attempted to discover what the cause or causes of the decreasing groundwater level might be. Nevertheless, decreasing groundwater levels are a complex problem. Several researchers cite improperly controlled residential, horticultural, and agricultural water usage as major causes for the groundwater decline in the region, while others claim the drilling and boring associated with petroleum, natural gas, and shale gas exploration are to blame. Other researchers suggest that sand ridge forests can affect groundwater considerably leading to decreased levels (Major 1974, 2002, Major - Neppel 1988, 1990, Szodfridt 1990, 1993, Pálfai 2010). Concerning all the viewpoints and interests of conservation treatment, water management, agriculture, and silviculture, it is crucial to initiate research into the water balance of the different forest stands. Examining the water balance process and dealing with its integration into conservation treatment is also essential. It could be useful if each sector determined the role of different forest stands in the water balance.

The main purpose of this paper is to provide information about the water balance features of sand ridge forest stands in the area of the Kiskunság National Park Directorate and to monitor the changes in different types of forests. While conducting the survey, the following are considered: (1) What impact do forest stands that are typical to the area have on changes in groundwater level? (2) What is the difference between the water balance of the examined ecosystems (deciduous, coniferous forests) and the neighbouring grasslands?

\section{MATERIALS AND METHODS}

\subsection{Research area}

Research was carried out in the area of the Kiskunság National Park Directorate (Figure 1). The two main sites comprised three forest stands in Bócsa (H: 19 29'38' W: 46 37' 37') and two other places in Pusztaszer (H: $20^{\circ}$ 02' 17' W: $\left.46^{\circ} 33^{\prime} 2^{\prime} 9^{\prime \prime}\right)$. In Bócsa, data were collected in two stands (Scots pine and grey poplar) and the surrounding grassland. The forest stands are homogeneous; the trees are the same age and were planted using the same technology. In Pusztaszer, the other main area of the research, data were collected in an old black locust forest stand that was established from second growth, and from the grassland next to it (Figure 1). 

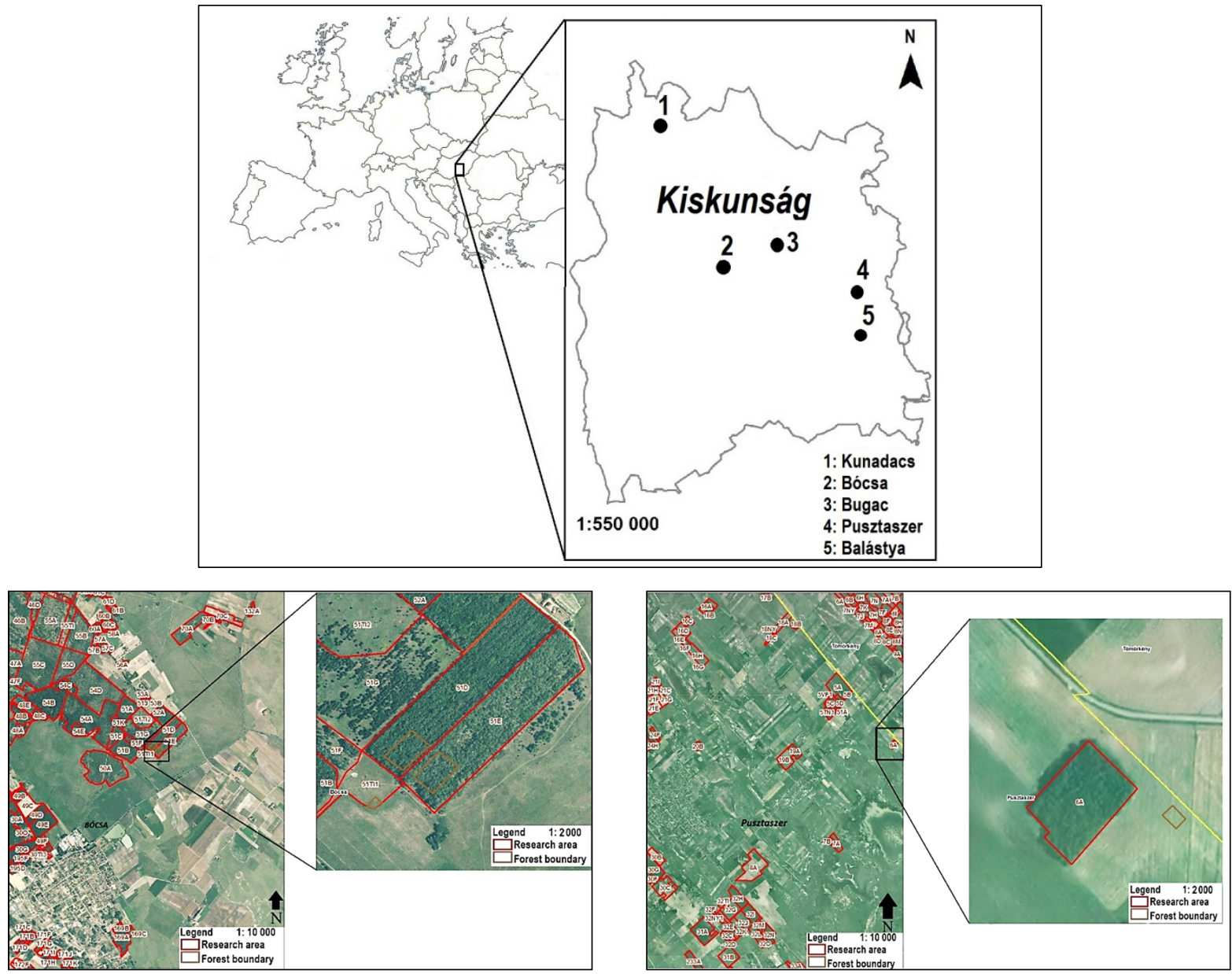

Figure 1. Research sites (Bócsa and Pusztaszer)

\subsection{Applied methods}

Open air precipitation was measured between March 2012 and March 2015 using Hellmann rain gauge units. Precipitation was assessed daily in Bócsa, Bugac and Pusztaszer; two observers assisted in our work in Balástya and Kunadacs (Figure 1).

We measured the throughfall and stemflow of a Scots pine monoculture stand (Bócsa $51 \mathrm{D}$ ) and a grey poplar monoculture stand (Bócsa $51 \mathrm{E}$ ) over the period from April 2012 to October 2014. Control measurements (groundwater level, soil moisture) were conducted in the grassland next to the above-mentioned forest stands (Bócsa 51 TI 1).

The throughfall was determined using Hellmann rain gauge units (one placed in a row of trees, another between two rows of trees, and the third placed in a thin grove). Twenty funnels (each $280 \mathrm{~cm}^{2}$ ) were also applied at every meter in both forests at 1 meter height from the ground. A further ten gauge units (each $100 \mathrm{~cm}^{2}$ ) were applied horizontally in a random way at the ground surface. For the calculation of stemflow, trunk collars (connected with collecting vessels) were placed on each tree. The trunk collar system was built with regard to the distribution of the tree trunk diameters (Figure 2).

Meteorological data (temperature, humidity, precipitation, radiation, speed, and wind direction) were collected with a BOREAS Meteo Global HI weather station employed in Bócsa (Bócsa 51 TI 1). This data collection was conducted hourly between January 2012 and March 2015. The groundwater level was observed hourly with Dataqua, LUB 222 sensors, and HYGR data loggers in Bócsa and Pusztaszer between November 2013 and February 2015. 


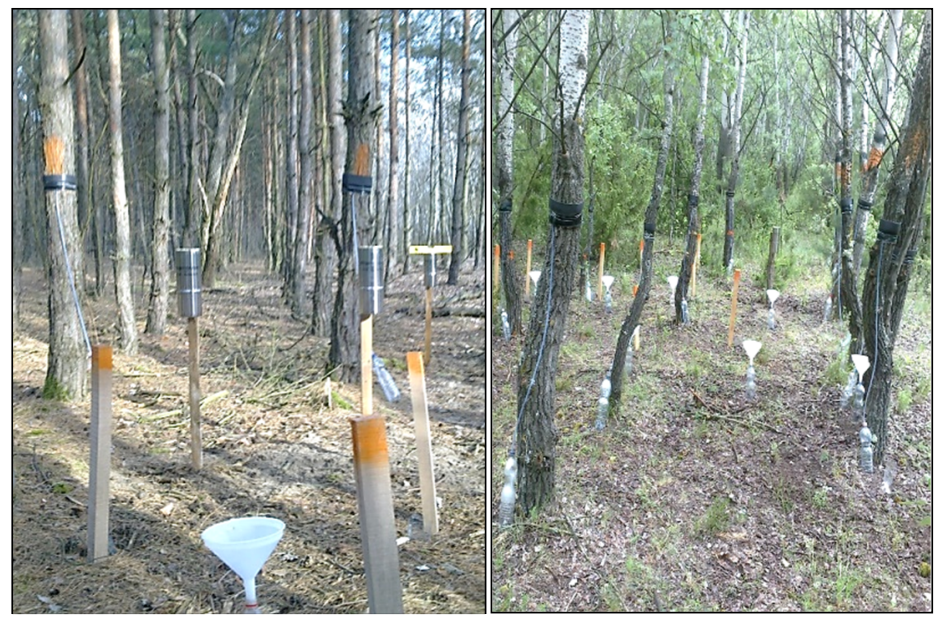

Figure 2. Trunk collar system with Hellmann rain gauge unit

To protect against possible data logger malfunction or failure, Dataqua, a DA-OP LED water gauge was used weekly for the manual detection of the groundwater level (Figure 3). Soil moisture data was recorded with a manual sensor (TDR-system digital PT-1) and with automatic data loggers in the grassland (Bócsa 51 TI 1), in the Scots pine stand (Bócsa 51 D) and in the grey polar stand (Bócsa $51 \mathrm{E}$ ). Automatic soil moisture measuring was surveyed with a HOBO MicroStation data logger manufactured by Onsetcomp and with twelve $10 \mathrm{HS}$ soil moisture sensors manufactured by Decagon.

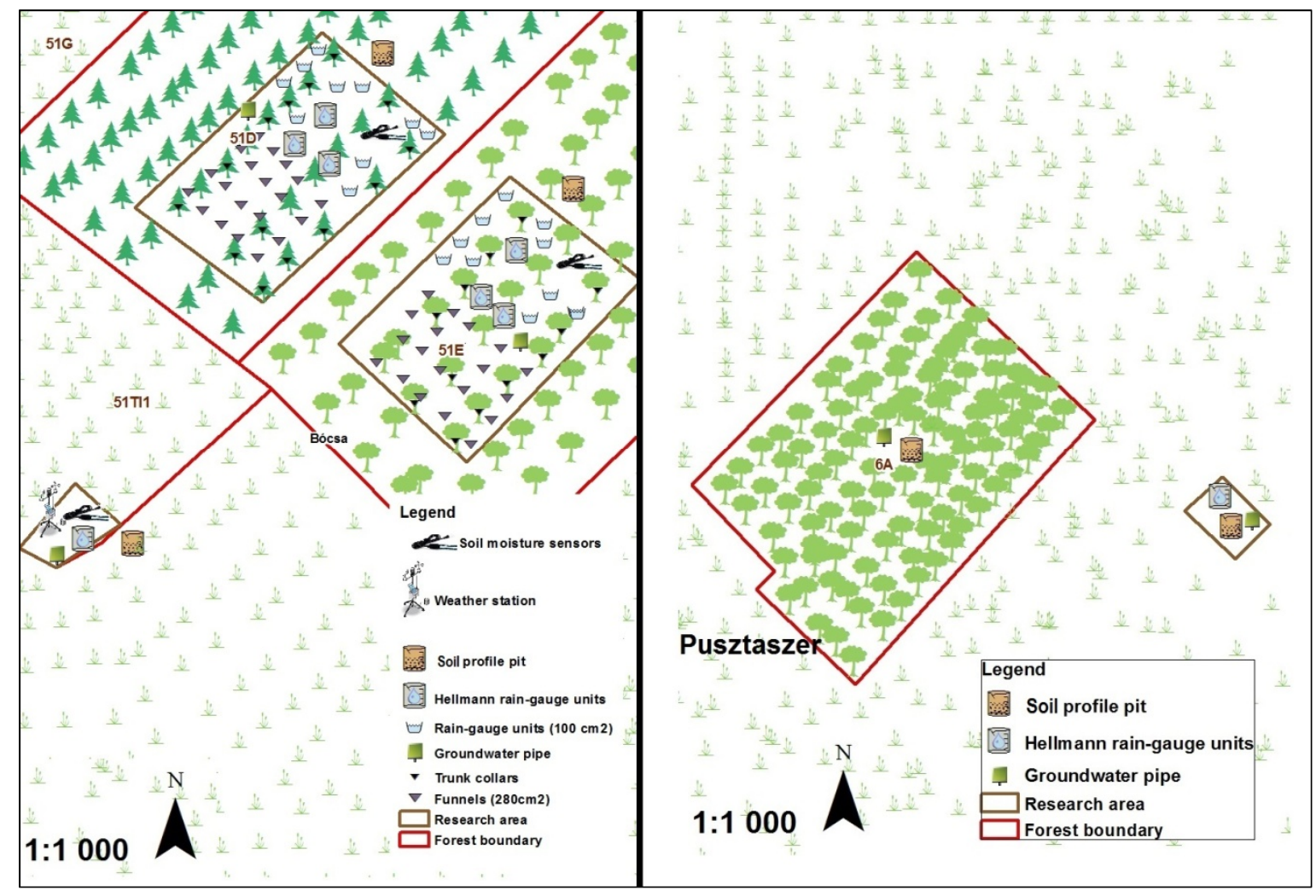

Figure 3. Distribution of the sensors in Bócsa and Pusztaszer 
The data collection took place in four soil layers $(0-25 \mathrm{~cm}, 25-50 \mathrm{~cm}, 50-75 \mathrm{~cm}, 75-100$ $\mathrm{cm}$, respectively) in each site between September 2013 and May 2014. The soil moisture was also observed manually with a TDR-system digital PT-1 soil moisture sensor manufactured by "Kapacitív Kkt" and it was measured in $80 \mathrm{~cm}$ bulk layers weekly. Soil moisture data were collected from December 2013 to March 2015.

\subsection{Processing data}

We processed the data collected during the research with the following methods:

- manual measurements (open air precipitation, throughfall, stemflow, groundwater, soil moisture) were processed with Microsoft Excel 2010 to clarify data. We also used Microsoft Excel 2010 to select and illustrate the data.

- automated soil moisture data were selected and analysed using authorised dataprocessing software. The false data were filtered by the mentioned software. On the other hand, the processing of meteorological and groundwater level data required the use of Microsoft Excel 2010 and extension programmes.

- the water balance equation was applied to estimate water balance (Szász - Tökei 1997) and the approach of White (White 1932, Loheide et al. 2005) was applied to the processed data of the survey. The water uptake from the groundwater of the forest stands was estimated with the method of White (White 1932).

The White method uses the following expression:

$$
E T_{G}=S_{Y}\left(\Delta s / t+R_{n}\right)
$$

Where:

$E T_{G}$ : the rate of evapotranspirative consumption of groundwater averaged over a 24-hour period $(\mathrm{L} / \mathrm{T})$,

$S_{Y}: \quad$ the specific yield (dimensionless),

$\Delta s: \quad$ daily change in storage (L),

$R_{n}: \quad$ the net inflow (recovery) rate $(\mathrm{L} / \mathrm{T})$,

$t: \quad$ the time period of one day expressed in the appropriate time units $(\mathrm{T})$.

The following equation was used to calculate the water balance (the water balance equation applied for lowland forests, from the top of the canopy down to the rooting depth):

$$
\Delta S=(P+C r)-(E T+Q+R+I)
$$

Where:

$\Delta S: \quad$ Change of the stored water in the layer,

$P: \quad$ Precipitation,

$C r: \quad$ Capillary rise $\left(E T_{G}\right.$ from the first equation),

ET: Evapotranspiration - transpiration of plants (from the soil moisture and from the groundwater) and evaporation of the ground surface (including the litter interception) -,

$Q: \quad$ Surface outflow,

$R: \quad$ Recharge to groundwater,

I: $\quad$ Crown interception

(we have neglected $P_{\text {micro }}$ : Microprecipitation at the ground surface, $S i$ : Surface inflow and Ssi: Subsurface inflow, Rss: Subsurface outflow were taken into account in capillary rise and recharge to groundwater).

We calculated transpiration with help of evapotranspiration and the evaporation. The previously mentioned water balance equation (Szász - Tökei 1997) was used for rainless seasons, so the values of interception and deep seepage were neglected; after that, the value of 
evapotranspiration was calculated from the restoration change of soil moisture (Moltschanow 1957, Gácsi 2000). During the rainless season, the soil moisture was measured and the restoration of soil moisture was calculated with the aforementioned data in the upper $100 \mathrm{~cm}$ soil layer.

From the obtained value of evapotranspiration, the evaporation was left and the value of transpiration was received. The forest evaporation data were used according to Járó (1981) and the evaporation data of grassland were used according to Hagyó (2009). The groundwater recharge was determined by the interception value and evapotranspiration as a remaining member of the water balance equation (Gácsi 2000).

The analysis of water fluxes of the sample areas was conducted by the water balance equation. The value of evaporation was estimated by the results of Járó (1981), Járó and Sitkey (1995) and Hagyó (2009). Járó (1981) estimated the value of the ground surface evaporation of the forest stand, which is equal with interception of the undergrowth and litter interception. The average of this value was taken into consideration. Hagyó estimated evaporation of the grassland with a SWAP model (van Dam 2000). The potential evapotranspiration was given with the Penman-Monteith equation according to Allen et al. (1998). The grassland results of Hagyó (2009) were also taken into account for the vegetation period.

\section{RESULTS}

During the three years of research, more than 354,800 data records were collected, out of which 6,137 records were collected manually and 348,663 were collected with data loggers. The spatial distribution of the precipitation varied in each sample area. Out of the five sample areas, the largest quantity of daily rainfall was recorded in Kunadacs on March 31, 2013 (60 mm) (Figure 4).

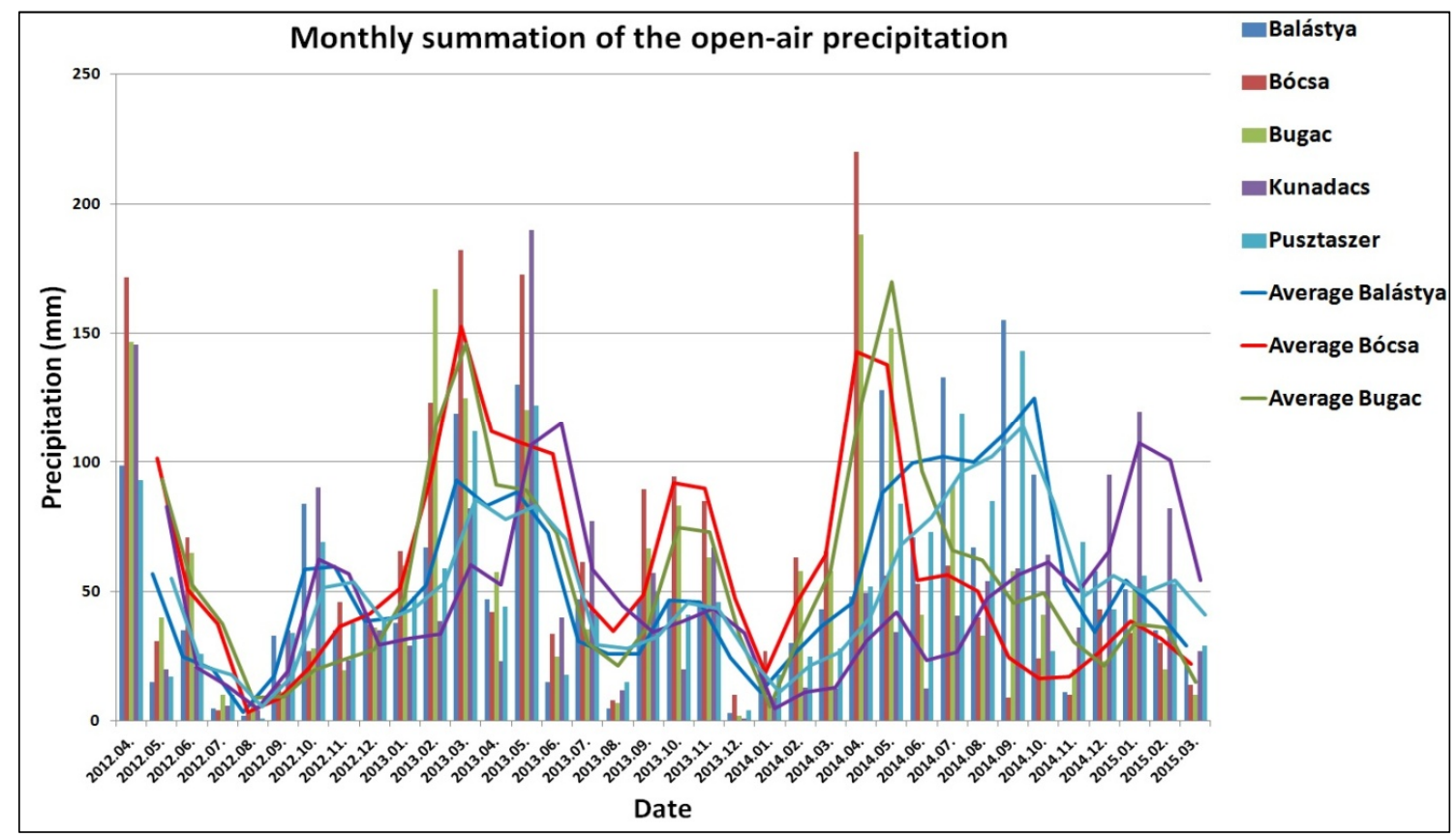

Figure 4. Time series of the precipitation in the research sites - April 2012-March 2015 (the moving average of the monthly summation of the open air precipitation) 
Meteorological data were similar to the average in Bócsa between January 1, 2012 and March 31, 2015, but extremes could be detected on several occasions (in extended dry periods in April and July 2013 as well as in June 2014). The total annual rainfall in 2012 was 420.6 $\mathrm{mm}$, which is below the Hungarian average data (omsz.hu); conversely, it was above the national average (omsz.hu) in $2013(599 \mathrm{~mm})$ and in $2014(807.9 \mathrm{~mm})$. Extended dry periods occurred in March, July, and August 2012, while August 2013 and March 2014 could be considered droughty (Figure 5). There were some dry periods typically in spring and in summer.

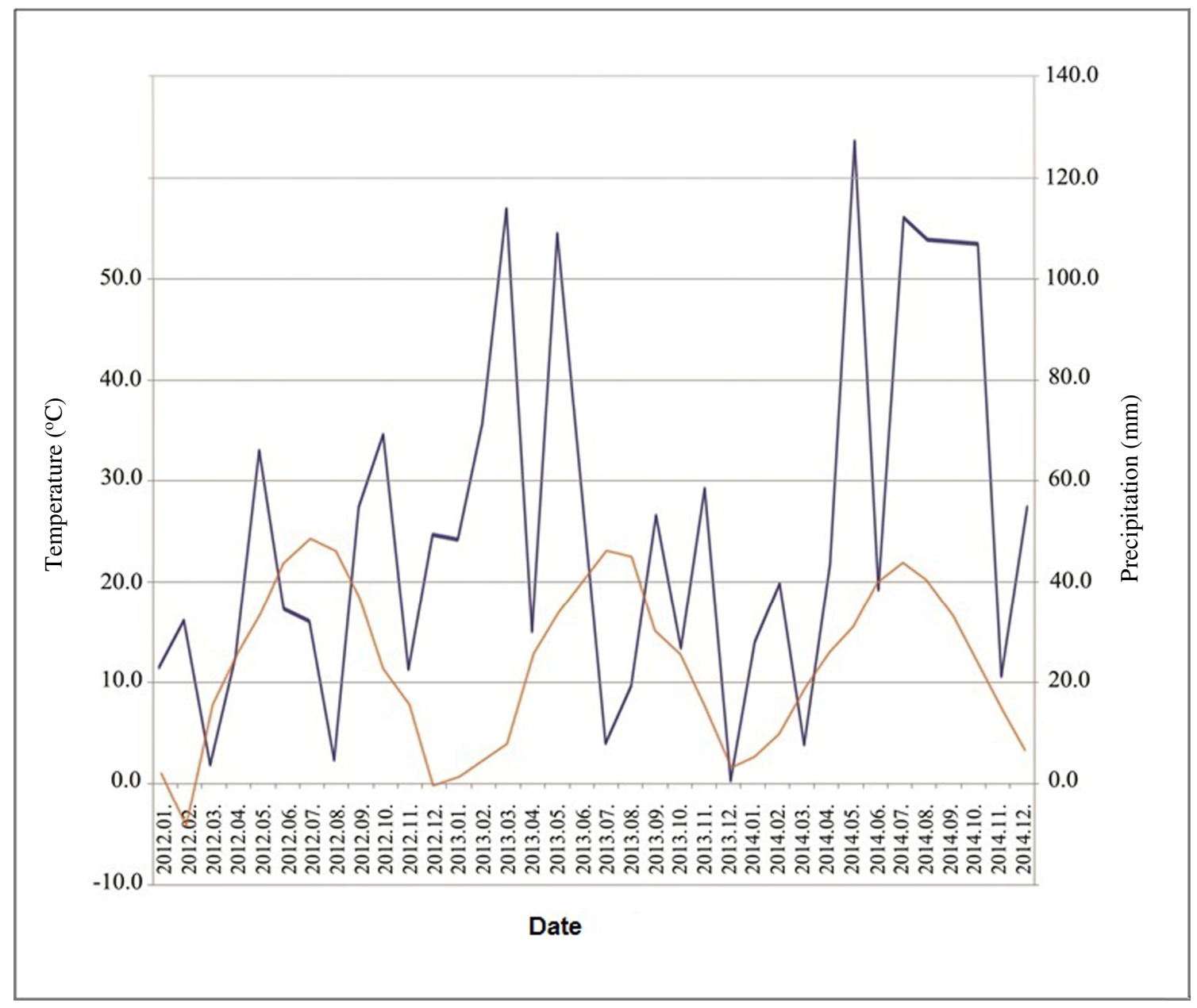

Figure 5. Climate graph of Bócsa 51 TI1

The average value of canopy interception was $23 \%$ in the Scots pine stand in Bócsa (in 2012: $22 \%$, in 2013: $24 \%$, in 2014: $23 \%$ ), while it was $19.2 \%$ in the grey poplar stand (in 2012: 18.5\%, in 2013: 20\%, in 2014: 19\%) between March 30, 2012 and March 31, 2015 (Figure 6).

The canopy interception was lower in the case of the grey poplar stand than the average published. This lower value can be explained by the lower canopy closure, the poor quality of trunks, the loose distribution of branches, missed treatments, and the many gaps caused by dead trees.

The interception of the grasslands was based on the results of Hagyó (2009) in Bugac. The interception of the black locust forest stand was determined by the results of Járó (1980). The stemflow value was 4\% in the Scots pine stand (in 2012: 1.5\%, in 2013: 4\%, in 2014: $2.5 \%$ ), and $10 \%$ in the grey poplar stand (in 2012: $8 \%$, in 2013: $12 \%$, in 2014: $10 \%$ ) during the period of March 30, 2012 and March 31, 2015. 
Stemflow value is lower in Scots pine stands because the tree bark is thick, rough, and absorbent. On the other hand, this value is higher in grey poplar stands, as the tree bark is smooth, thereby allowing more rainfall to flow down the trees.

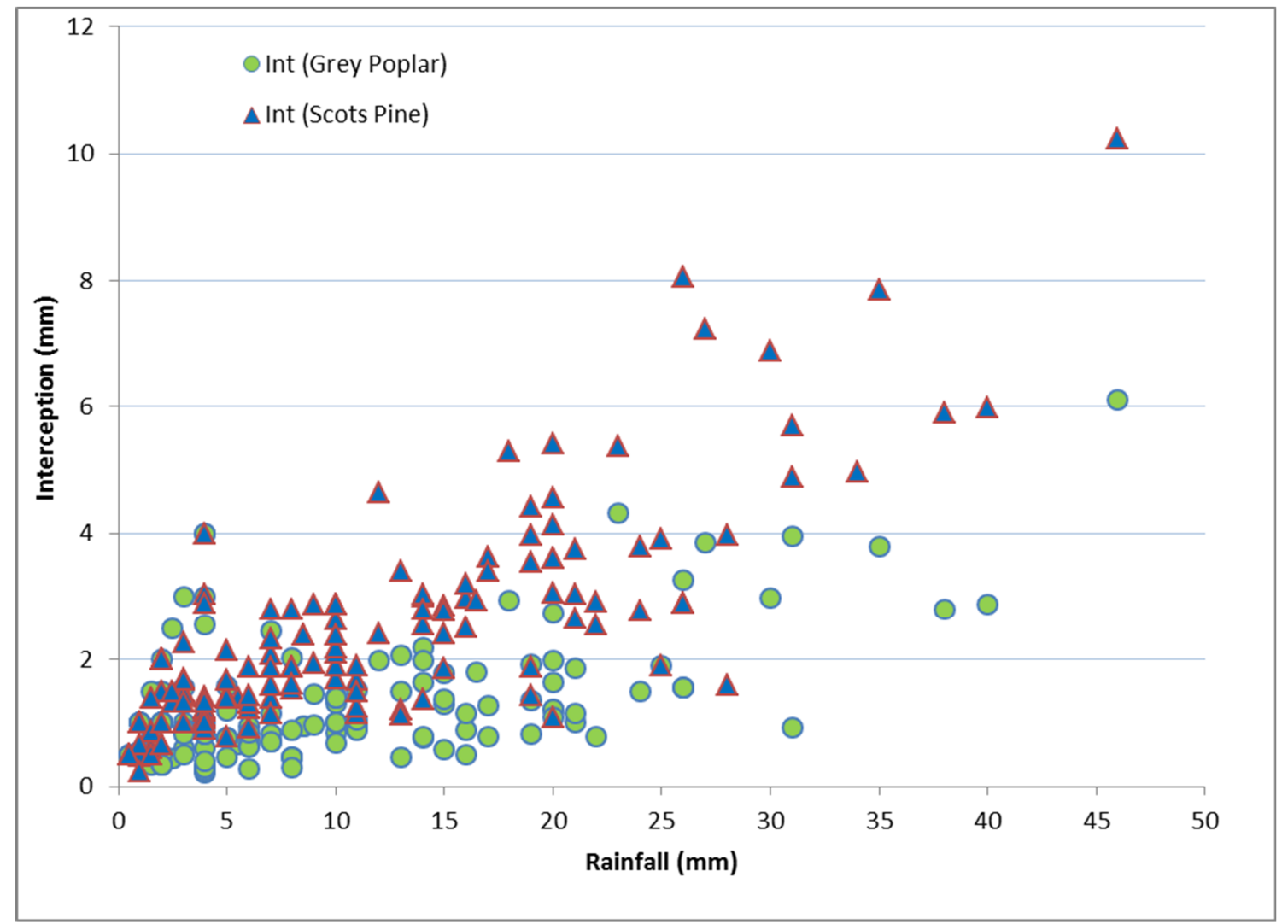

Figure 6. Interception as a function of rainfall (between March 2012 and March 2015)

The groundwater level was usually detected at $3.4 \mathrm{~m}$ (below the terrain) in Bócsa over the period of November 25, 2013 and February 2, 2015. This level is regarded as relatively deep for vegetation groundwater use in the Great Hungarian Plain, but in the region of the Kiskunság Sand Ridge, it is a typical value. It seems to be average according to former references (Gácsi 2000) and by the Directorate of Water Management in Szeged: $3.5 \mathrm{~m}$ (below the terrain) in Orgovány and $3.3 \mathrm{~m}$ (below the terrain) in Bócsa in 2014.

The average value of groundwater level was $2.1 \mathrm{~m}$ in Pusztaszer during the research period. This value of $2.1 \mathrm{~m}$ is above the average in Kiskunság Sand Ridge compared with the data of 2.8 $\mathrm{m}$ in Ópusztaszer in 2014, and $2.9 \mathrm{~m}$ in Balástya in 2014 compiled by the Directorate for Environmental Protection and Water Management of the Lower Tisza District in Szeged. Analysing groundwater level records, significant differences can be detected between the grassland and the forest stand. Our results also establish that lower groundwater level records are typical under forest stands; during the vegetation period, the groundwater level under forest was $38 \mathrm{~cm}$ lower in Bócsa, while it was $47 \mathrm{~cm}$ lower in Pusztaszer (Figure 7 and Figure 8).

Black locust and grey poplar stands are able to reach and uptake groundwater from deeper layers with their roots (Keresztesi 1969, Kárász 1986, Csiha - Keserü 2014). The diurnal signal was observed in the black locust and grey poplar stands; therefore, the water uptake from the groundwater was estimated (Gribovszki et al. 2010). The studied coniferous stands are unable to reach and uptake the groundwater from deeper layers (the diurnal signal was not observed). Thus, coniferous stands can only affect groundwater levels by interception throughout the year. 


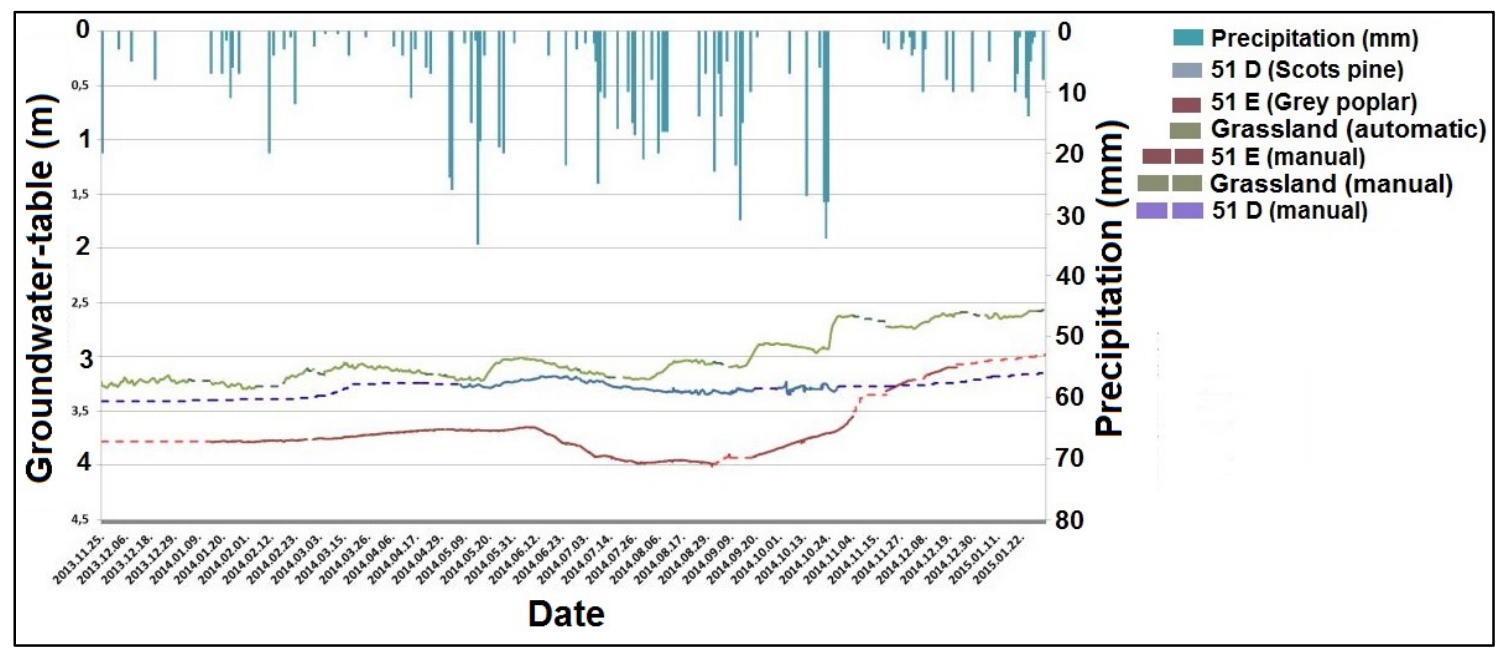

Figure 7. Changes in the water table in Bócsa

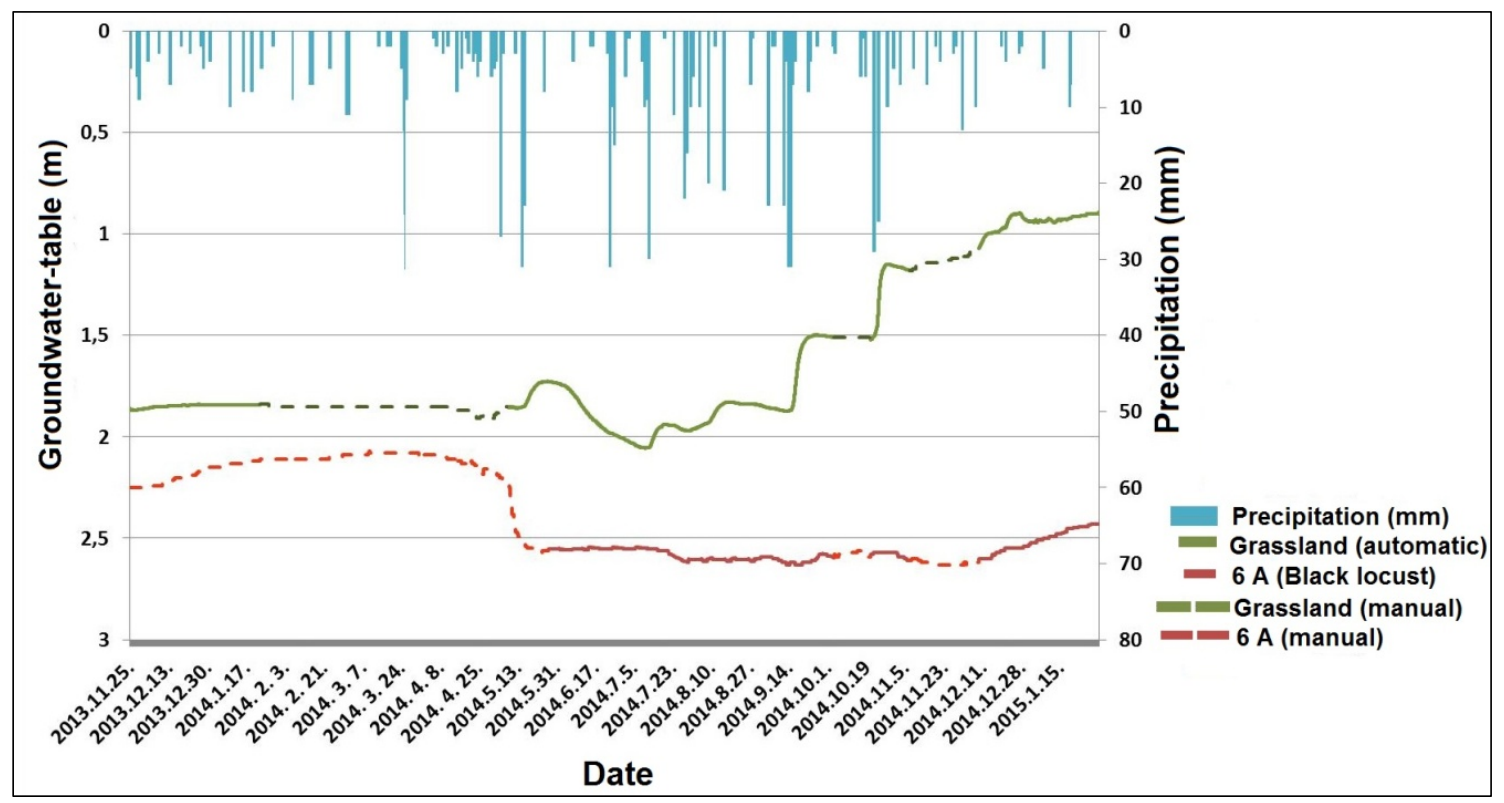

Figure 8. Changes in the water table in Pusztaszer (upper $80 \mathrm{~cm}$ )

In the case of soil moisture in Bócsa, the differences between grasslands and forest stands were obvious in the sample area of Pusztaszer (The value of soil moisture was 3\% lower in Bócsa and 4\% lower in Pusztaszer). The soil moisture data detected in the grasslands followed the distribution of daily precipitation evidently. On the contrary, in the black locust forest stands the value of soil moisture followed the daily rainfall slowly and unevenly (Figure 9). The reason for the low moisture contents during the summer was the increased water use in the vegetation period. With a developed root system, the sprouts of black locust forest stands can dry the upper soil level within a short time ( 10 days), which has a great influence on the quantity of infiltration during the vegetation period. 


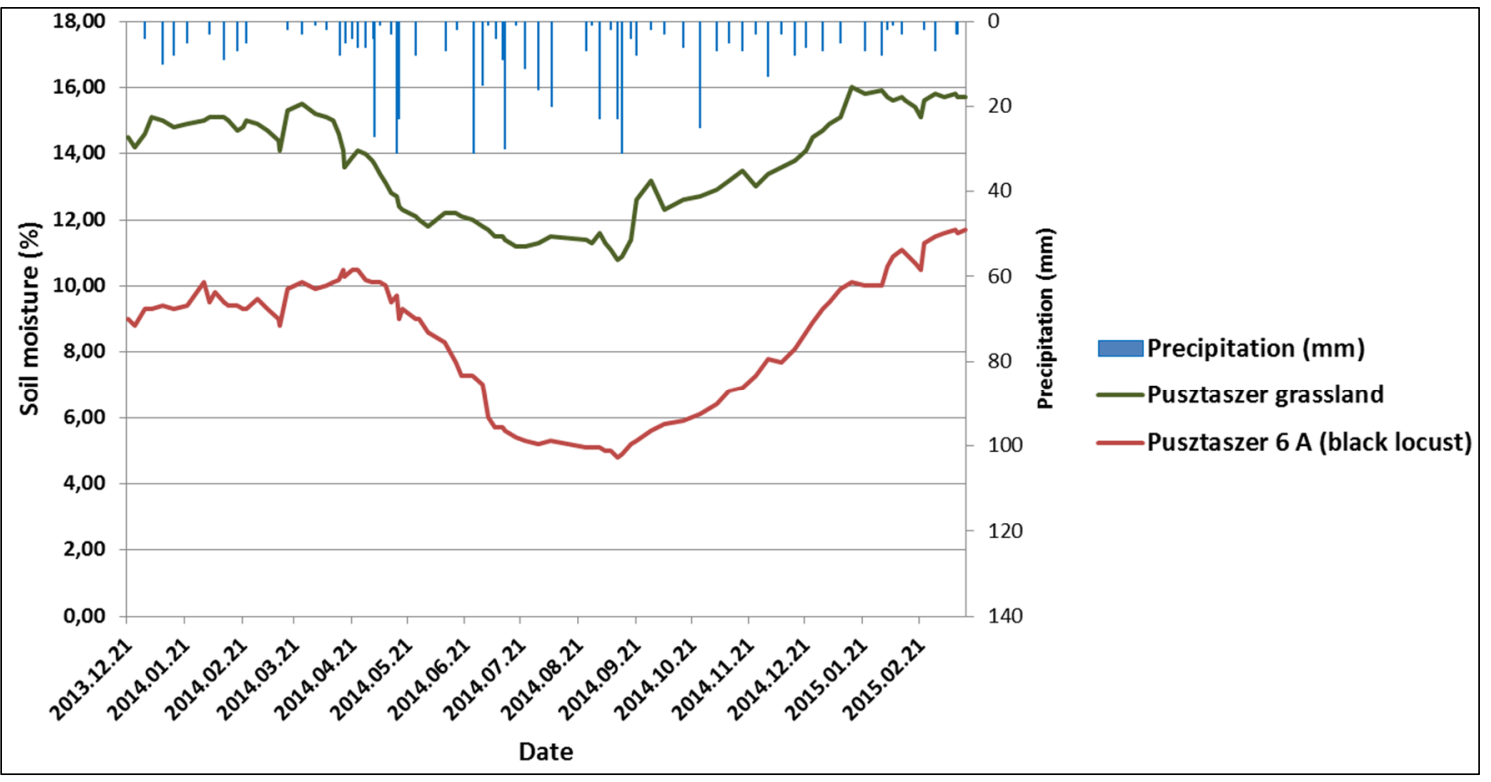

Figure 9. Fluctuation of the soil moisture in Pusztaszer PT-1 (upper $80 \mathrm{~cm})$

The soil moisture in the upper soil layer $(0-25 \mathrm{~cm})$ of the control grassland area was the most diverse, while the moisture content was more balanced in the deepest layer.

In Bócsa, the increase of the moisture content was observed in all of the four soil layers in the late autumn-early winter period; following that, a temporary decrease was detected.

The late winter precipitation and snow melting affected an increase in the value of the soil moisture; then, a decrease in the soil moisture of the grassland starts again at the beginning of the vegetation period (Figure 10).

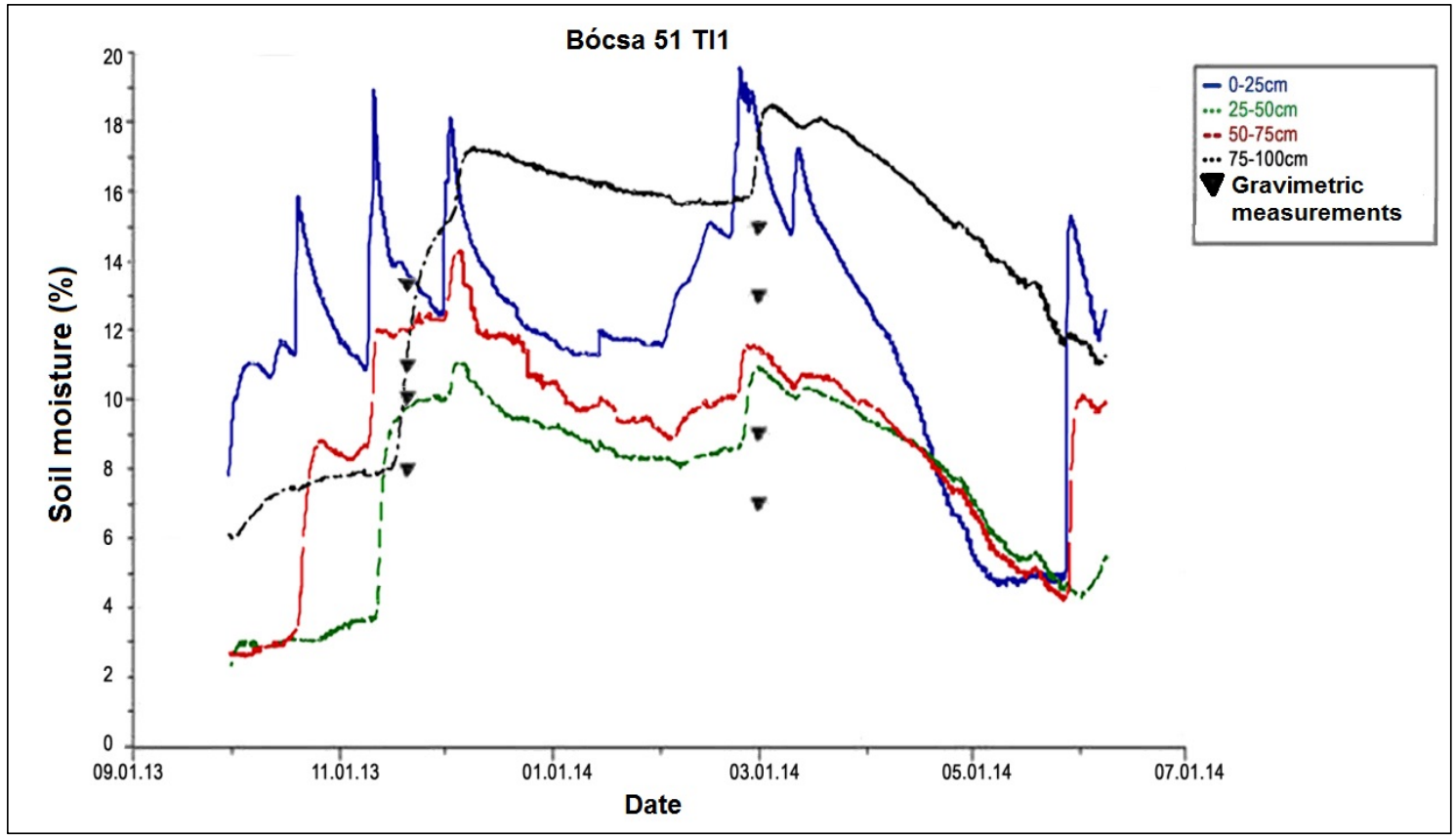

Figure 10. Fluctuation of the soil moisture in Bócsa 51TI1(10HS)

The soil moisture content of the Scots pine stand (Bócsa 51 D) was almost the same in the two upper layers $(0-25 \mathrm{~cm}, 25-50 \mathrm{~cm})$. The third soil layer $(50-75 \mathrm{~cm})$ partly follows the periodic changes of the two upper soil layers. A continuous increase tendency was observed in the lowest soil layer $(75-100 \mathrm{~cm})$ (Figure 11). 


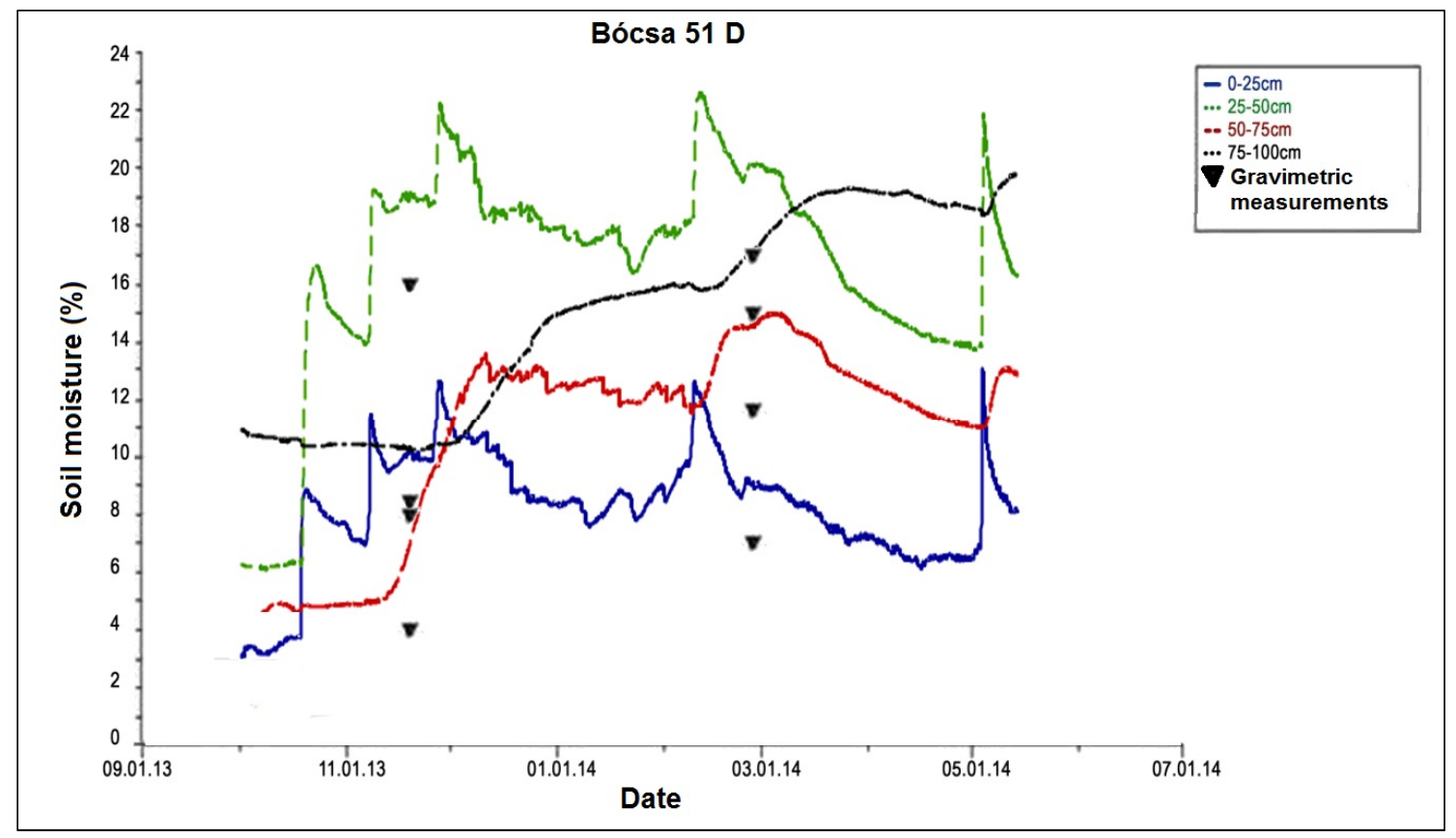

Figure 11. Fluctuation of the soil moisture in Bócsa $51 D(10 H S)$.

As for the grassland, the value of the soil moisture content of the pine stand starts to increase in late autumn. Following a short decrease period in the beginning of winter, there is a sudden increase, as Hagyó published in 2009. During the spring months, the value of the soil moisture shows a decreasing tendency. The reasons for the lower moisture content in the pine forest are the deeper root system of the trees and the loss of the interception.

Similar moisture content dynamics of the four soil layers was observed in the grey poplar stand (Bócsa 51 E). Generally, larger soil moisture content fluctuation characterizes the poplar stands. As mentioned earlier, the value of the soil moisture content of the poplar stand also starts to increase in late autumn, followed by a short decrease period in the beginning of winter, which then turns into a sudden increase. During the spring and early summer, the value of the soil moisture usually shows a decreasing tendency (Figure 12).

The spring decrease of the soil moisture could relate to the well-developed root system of the poplar stand.

In our research, the calculation (estimating) of water balance elements was based on field measurements as well as the basic values; published data were set with the help of field measurements. The value of evaporation is $95 \mathrm{~mm}$ in forest stands, and $125 \mathrm{~mm}$ in the case of the grasslands (based on Járó 1981, Hagyó 2009).

The differences in evaporation were significant regarding the grassland, the coniferous stand, and deciduous stands in the case of transpiration. The difference was noticeable between the grassland and the two forest stands. Transpiration in the coniferous stand was lower because the roots were unable to reach the groundwater level. The Scots pine can only uptake water from rainfall infiltrating into the soil. The value of evapotranspiration was the highest in the case of the grey poplar stand (Table 1). Deciduous stands have extensive roots so they more easily access groundwater in the upper layers. 


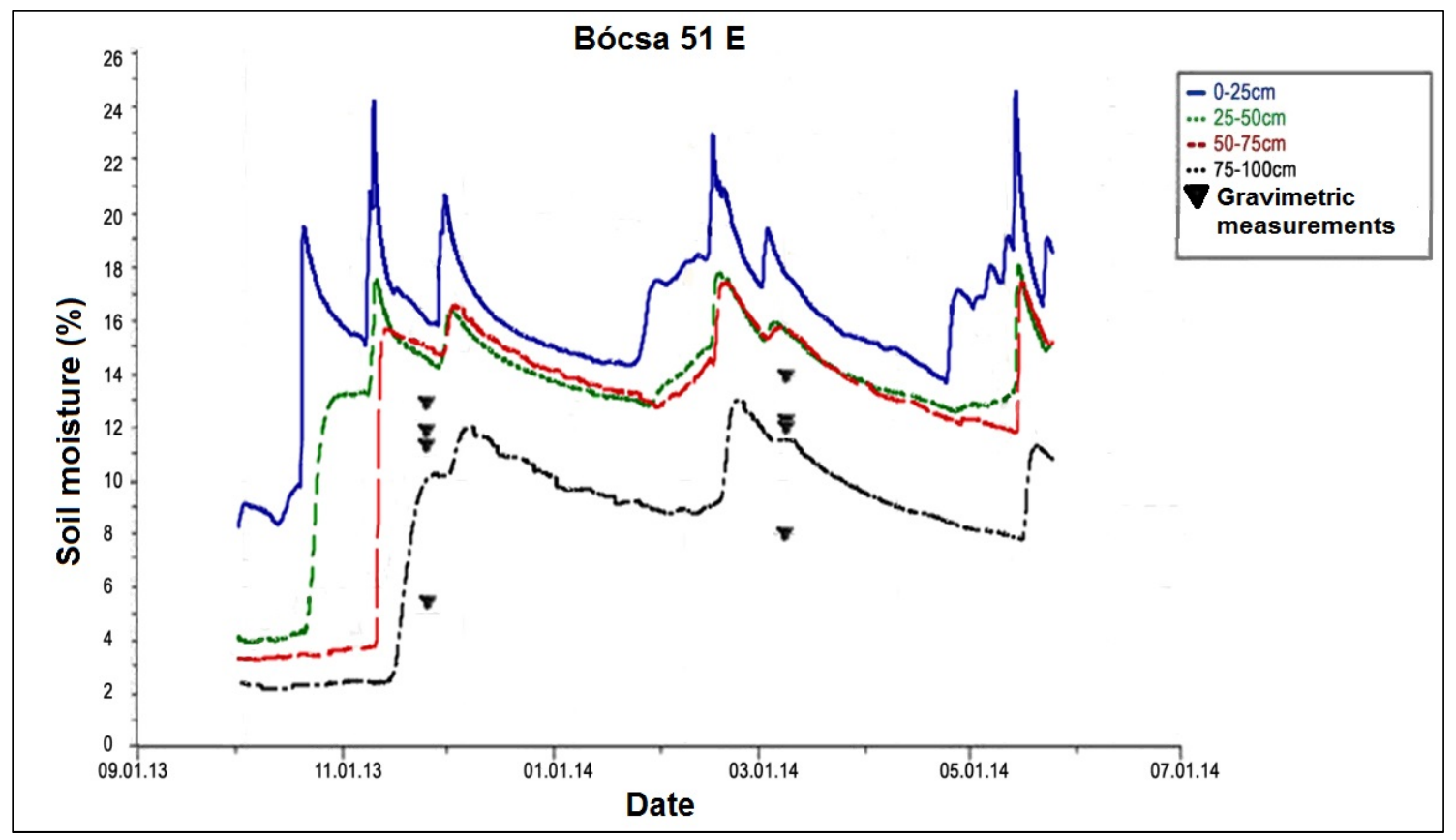

Figure 12. Fluctuation of the soil moisture in Bócsa 51E (10HS)

Table 1. Water balance elements

\begin{tabular}{|c|c|c|c|c|c|c|}
\hline \multirow{3}{*}{$\begin{array}{l}\text { Date } \\
\text { Research sites } \\
\text { Precipitation }\end{array}$} & \multicolumn{6}{|c|}{31 March - 01 September 2014} \\
\hline & \multicolumn{2}{|c|}{$\begin{array}{l}\text { Bócsa } 51 \mathrm{D} \\
\text { (Scots pine) }\end{array}$} & \multicolumn{2}{|c|}{$\begin{array}{l}\text { Bócsa 51 E } \\
\text { (grey poplar) }\end{array}$} & \multicolumn{2}{|c|}{$\begin{array}{l}\text { Bócsa TI1 } \\
\text { (grassland) }\end{array}$} \\
\hline & $428 \mathrm{~mm}$ & $100 \%$ & $428 \mathrm{~mm}$ & $66 \%$ & $428 \mathrm{~mm}$ & $100 \%$ \\
\hline Interception & $98 \mathrm{~mm}$ & $23 \%$ & $81 \mathrm{~mm}$ & $12 \%$ & $30 \mathrm{~mm}$ & $7 \%$ \\
\hline Evaporation & $95 \mathrm{~mm}$ & $22 \%$ & $95 \mathrm{~mm}$ & $15 \%$ & $125 \mathrm{~mm}$ & $29 \%$ \\
\hline $\begin{array}{l}\text { Transpiration } \\
\text { (from vadose zone and from groundwater) }\end{array}$ & $205 \mathrm{~mm}$ & $48 \%$ & $405 \mathrm{~mm}$ & $62 \%$ & $85 \mathrm{~mm}$ & $20 \%$ \\
\hline Total recharge & $88 \mathrm{~mm}$ & $20 \%$ & $153 \mathrm{~mm}$ & $23 \%$ & $229 \mathrm{~mm}$ & $53 \%$ \\
\hline Capillary rise & - & - & $230 \mathrm{~mm}$ & $34 \%$ & - & - \\
\hline Change of the water content of the soil & $-58 \mathrm{~mm}$ & $-13 \%$ & $-76 \mathrm{~mm}$ & $-12 \%$ & $-41 \mathrm{~mm}$ & $-9 \%$ \\
\hline Date & \multicolumn{6}{|c|}{31 March - 01 September 2014} \\
\hline Research sites & \multicolumn{3}{|c|}{$\begin{array}{l}\text { Pusztaszer TI } \\
\text { (grassland) }\end{array}$} & \multicolumn{3}{|c|}{$\begin{array}{c}\text { Pusztaszer 6 A } \\
\text { (black locust) }\end{array}$} \\
\hline Precipitation & $407 \mathrm{~mm}$ & & $100 \%$ & $407 \mathrm{r}$ & & $75 \%$ \\
\hline Interception & $28 \mathrm{~mm}$ & & $7 \%$ & $102 r$ & & $19 \%$ \\
\hline Evaporation & $125 \mathrm{~mm}$ & & $31 \%$ & $95 r$ & & $17 \%$ \\
\hline $\begin{array}{l}\text { Transpiration } \\
\text { (from vadose zone and from groundwater) }\end{array}$ & $135 \mathrm{~mm}$ & & $33 \%$ & $370 \mathrm{r}$ & & $68 \%$ \\
\hline Total recharge & $168 \mathrm{~mm}$ & & $41 \%$ & $43 r$ & & $8 \%$ \\
\hline Capillary rise & - & & - & $136 r$ & & $25 \%$ \\
\hline Change of the water content of the soil & $-49 \mathrm{~mm}$ & & $-12 \%$ & $-67 r$ & & $-12 \%$ \\
\hline
\end{tabular}




\section{DISCUSSION AND CONCLUSIONS}

We measured open air precipitation by using Hellmann rain-gauge units in five sample areas (in Balástya, Bócsa, Bugac, Kunadacs and Pusztaszer). A groundwater level measuring system was applied in five sites in Bócsa and in Pusztaszer. In Bócsa, we operated a weather station in one sample area, and we used an automatic moisture measuring system in three sample areas. If this measuring system was developed further, it could be connected to other systems such as the Forest Research Institute and could be used for long-term research in the future.

Analysing the interception data, we found that the interception values are affected by rainfall, that is, by its quantity, intensity, distribution and physical features. Interception values are also affected by the structure of the forest stands, that is, by the type of tree species, by tree trunk shape and distribution, tree density, and the foliage and the health of the forest stand. The values of the interception measured in the Scots pine forest stand can be regarded as higher than the former results. In the grey poplar stand, the values of interception were lower than the average values, which can be explained by the lower foliage, the poor quality of trunks, and the weak density of the branches as well as the leaks due to the dead trees in the stand. When we compared canopy interception with the published data (Járó 1980: 16\%, Gácsi 2000: 19.5\%, Sitkey 2004: 25\%), our results in the Scots pine stand proved to be a bit above the previously published average.

It is difficult to compare the results with former references (Járó 1980: 24\%, Sitkey 2004: $23 \%$ ) since they refer to stands of different age, source, and growth.

Analysing stemflow values, we found that there is less stemflow in pine forest stands, as pine has thick, absorbent bark. However, the stemflow value was higher in the grey poplar stand since grey poplar has smooth bark, which helps water flow down the trunks. It is not always feasible to compare the results with the results found in literature because of the differences in forest stands and measuring methods. In the case of stemflow, it is also difficult to compare references (Járó 1980, Gácsi 2000, Sitkey 2004) since they contain only interception data regarding stemflow as a negligible quantity.

Groundwater levels typically presented lower values under the examined forest stands throughout our research (Móricz et al. 2012, Gribovszki et al. 2014, Tóth et al. 2014). The grey poplar stand in Bócsa and the black locust stand in Pusztaszer are able to reach and uptake the groundwater from the deeper layers with the help of their root system. The examined Scots pine stand does not affect the groundwater levels as much as the deciduous forest stands do. This statement corresponds to the results by Gácsi 2000; on the other hand, it contradicts to the hypotheses by Major and Neppel (Major - Neppel 1988, Major 1994, 2002)

The difference in the fluctuation of soil moisture between the grasslands and the forest stands is obvious in Bócsa and in Pusztaszer. The data collected prove that the examined forest stands uptake more water from deeper layers with the help of their root system (layers which cannot be reached by herbaceous vegetation). This phenomenon affects deep seepage as well. The herbaceous vegetation influences soil moisture in the upper layers of the soil between $0-50 \mathrm{~cm}$. On the other hand, the values of soil moisture decrease in layers between $75-100 \mathrm{~cm}$ as well in the case of deciduous forest stands in the growing season. In the forest stands and in the grasslands, the volumes of soil moisture were similar to the results published by Hagyó in 2009. The fluctuation of the soil moisture values in the two upper layers $(0-25 \mathrm{~cm}, 25-50 \mathrm{~cm})$ in the coniferous stand was similar to the results by Gácsi 2000 . In the deeper layers of the ground $(50-75 \mathrm{~cm}, 75-100 \mathrm{~cm})$, the measured soil moisture values are more balanced and display typical trends.

By using the water balance equation, it is clear that the transpiration of both grasslands were much lower $(85 \mathrm{~mm}$ and $135 \mathrm{~mm})$ than that of the neighbouring forest stands. The value 
of transpiration was lower $(205 \mathrm{~mm})$ in the Scots pine stand, since its root system does not reach the groundwater level. Coniferous stands can only uptake the water from layers infiltrated by rainfall. The value of transpiration was the highest in the grey poplar and black locust forest stands (405 $\mathrm{mm}$ and $370 \mathrm{~mm}$ ) as the trees can uptake the water from the upper and the deeper layers with the help of their expanded root system. The values of the capillary rise were $136 \mathrm{~mm}$ in the black locust stand and $230 \mathrm{~mm}$ in the grey poplar stand.

Acknowledgements: Research has been supported by the following funds: "OTKA (NN 79835)" and the "AGRÁRKLÍMA.2 (VKSZ_12-1-2013-0034)".

\section{REFERENCES}

Allen, R.G. - PereiRA, L.S. - RAES, D. - SMith, M. (1998): Crop evapotranspiration - Guidelines for computing crop water requirements. FAO Irrigation and drainage paper 56.

CSIHA, I. - KESERÜ, Zs. (2014): Szárazodó homoki termőhelyen álló idős fák gyökérzetének vizsgálata. [Investigation of rooting zone of forest association growing under drying sandy site conditions] Erdészettudományi Közlemények 4 (2): 33-42. (in Hungarian)

GÁCSI, Zs. (2000): A talajvízszint észlelés, mint hagyományos, s a vízforgalmi modellezés, mint új módszer Alföldi erdeink vízháztartásának vizsgálatában. [Soil water level observation as traditional method and the water flow modelling as a new method to study the water supply of lowland forests. PhD dissertation] Doktori (PhD) értekezés, NyME, 69-93. (in Hungarian)

GRIBOVSZKI, Z. - SZILÁGYI, J. - KALICZ P. (2010): Diurnal fluctuations in shallow groudwater levels and in streamflow rates and their interpretation - a review. Journal of Hydrology 385: 371-383.

GribovsZKi, Z. - KAlicZ, P. - BAlOG, K. - SZABÓ, A. - TóTH, T. (2014): Comparison of groundwater uptake and salt dynamics of an oak forest and of a pasture on the Hungarian Great Plain. Acta Silv. Lign. Hung. 10 (1): 103-114.

HAGYÓ, A. (2009): Vízforgalom gyep és erdőterületeken. [Water cycle in forests and grasslands, $\mathrm{PhD}$ dissertation] Doktori (PhD) értekezés, SZIE. 17-93. (in Hungarian)

JÁRÓ, Z. (1980): Intercepció a gödöllői kultúr erdei ökoszisztémában. [Interception of the cultivated forest ecosystem of Gödöllő] Erdészeti kutatások 73 (1): 7-17. (in Hungary)

JÁRÓ, Z. (1981): A hazai erdők vízfogyasztása. [The consumption of Hungarian forest] Agrártudományi közlemények, 40 (2-4): 353-356. (in Hungarian)

JÁRó, Z. - SITKEY, J. (1995): Az erdő és a talajvíz kapcsolata. [The relation of forest and soil water] Erdészeti kutatások 85 (1): 35-49. (in Hungarian)

KÁRÁSZ, I. (1986): Gyökérvizsgálatok Magyarországon. [Studies of roots in Hungary.] Botanikai közlemények 73 (1): 19-23. (in Hungarian)

KERESZTESI, B. (1969): Beszámoló a Nemzetközi Biológiai Program (IBP) „A gyökérzet és a rizoszférában élő szervezetek produktivitásának módszerei" címú szimpóziumáról (MoszkvaLeningrád-Dusanbe, 1968. augusztus 28. - szeptember 12.). [Report on the symposium of the International Biology Program „Methods of the organism living on the roots and in the rhizosphere"] Erdészeti Kutatások 65 (1): 329-363. (in Hungarian)

LOHEIDE, S. P. - BUTLER, J. J. - GORELICK, S. M. (2005): Estimation of groundwater consumption by phreatophytes using diurnal water table fluctuations: A saturated-unsaturated flow assessment. Water resources research 41(1):1-14.

MAJOR, P. (1974): Síkvidéki erdők hatásának vizsgálata a talajvízpárolgás és tényleges beszivárgás folyamataira. [Effects of the lowland forest on soil water evaporation and effective infiltration] Hidrológia Közlöny 54 (6): 281-288. (in Hungarian)

MAJOR, P. (1994): Talajvízszint-süllyedések a Duna-Tisza közén [Soil water level sinking in DanubeTisza Sandrige] In: Pálfai I. (szerk.): A Duna-Tisza közi hátság vízgazdálkodási problémái. Nagyalföld Alapítvány, Békéscsaba. 17-24. (in Hungarian)

MAJOR, P. (2002): Síkvidéki erdők hatása a vízháztartásra. [Effect of the lowland forests on the water supply] Hidrológiai Közlöny 82 (6): 319-323. (in Hungarian) 
MAJOR, P. - NEPPEL, F. (1988): A Duna-Tisza közi talajvízszint-süllyedések. [Soil water level sinking in Danube-Tisza Sandrige] Vízügyi Közlemények 70 (4): 605-626. (in Hungarian)

MAJOR, P. - NEPPEL, F. (1990): VITA: Válasz Szodfridt István hozzászólására (Megjelent a Vízügyi Közlemények 1990. évi 3. füzetében a 287-291. oldalon.) [DISPUTE: Answer for the comment of István Szodfridt] Vízügyi Közlemények 70 (4): 402-406. (in Hungarian)

Móricz, N. - MÁtYÁs, Cs. - BERKI, I. - RASZTOVITS, E. - VEKERDY, Z. - GRIBOVSZKI, Z. (2012): Egy erdő- és parlagterület vízforgalmának összehasonlítása. [Comparative water balance study of forest and fallow plots] Hidrológiai Közlöny 92 (1): 67-74. (in Hungarian)

PÁLFAI, I. (1993): Talajvízszint-süllyedés a Duna-Tisza közén. [Soil water level sinking in DanubeTisza Sandrige] Vízügyi közlemények 75 (4): 431-434. (in Hungarian)

PÁLFAI, I. (2010): A Duna-Tisza közi hátság vízgazdálkodási sajátosságai. [The specialities of the water management in the Danube-Tisza Sandridge] Hidrológia Közlöny 90 (1): 40-44. (in Hungarian)

SitKeY, J. (2004): Csapadékvíz vizsgálatok ökológiai bázisterületeken - In: Barna T. (szerk.): Tudományos eredmények a gyakorlatban. [Rainfall researches in ecological base areas - In: T. Barna (ed.): Scientific results in practice] Alföldi Erdőkért Egyesület, Kecskemét. 32-37. (in Hungarian)

SZÁSZ, G. - TŐKEI, L. (1997): Meteorológia mezőgazdáknak, kertészeknek, erdészeknek. [Meteorology for farmers, gardeners, foresters] Mezőgazda Kiadó, Budapest. 772 p. (in Hungarian)

SZODFRIDT, I. (1990): HOZZÁSZÓLÁS: Major Pál és Neppel Ferenc: A Duna-Tisza közi talajvízszint-süllyedése címü cikkéhez. (Megjelent a Vízügyi Közlemények 1988. évi 4. füzetének 605-626. oldalán.) [COMMENT: Pál Major and Ferenc Nepper: Soil water level sinking in Danube-Tisza Sandrige] Vízügyi Közlemények 72 (3): 287-291. (in Hungarian)

SzODFRIDT, I. (1993): Az erdő és a talajvizek kapcsolata Duna-Tisza közi hátságon. [The relation ofthe forest and the soil water in Danube-Tisza Sandridge] Hidrológia Közlöny 73 (1): 44-45. (in Hungarian)

Tóth, T. - BALOG, K. - SzABó, A. - PÁszToR L. - JobbÁGy, E. G. - NosetTo, M. D. - GRibovszKi, Z. (2014): Influence of lowland forests on subsurface salt accumulation in shallow groundwater areas. AoB PLANTS plu054, 6: 1-39.

VAN DAM, J.C. (2000): Field-scale water flow and solute transport. SWAP model concepts, parameter estimation and case studies. Doctoral Thesis Wageningen University.

WHITE, W.N. (1932): A method of estimating ground-water suppliesbased on discharge by plants and evaporation from soil: Results of investigations in Escalante Valley, Utah, U.S. Geol. Surv. Water Supply Pap., 659-A. 